\title{
Kryzysowa polityka pieniężna - podstawowe dylematy
}

\section{Jacek Tomkiewicz ${ }^{1}$}

Nadesłany: 11.12.12 | Zaakceptowany do druku: 20.03.13

\begin{abstract}
Abstrakt
Cel: Celem tekstu jest wskazanie problemów, przed którym stoją obecnie banki centralne. Wobec bardzo aktywnego zaangażowania się ich w proces usuwania skutków kryzysu finansowego można wskazać wiele dylematów, które związane są z bieżącą polityką pieniężną, a które nie zostały jednoznacznie rozstrzygnięte na gruncie teoretycznym. Na razie trudno także mówić o całościowym bilansie ekspansywnej polityki monetarnej, która wprawdzie przyczyniła się do spłycenia recesji i ograniczyła ryzyko panujące na rynkach finansowych, ale wiąże się także z narastaniem negatywnych procesów, które mogą być w przyszłości zagrożeniem dla stabilności gospodarki.

Metodologia: Tekst ma charakter teoretyczny, rozważania prowadzone są na podstawie przeglądu bieżącej literatury przedmiotu i analizy podstawowych danych statystycznych.

Podstawowe wyniki: $W$ tekście wskazuje się na podstawowe kwestie, które mają obecnie do rozstrzygnięcia główne banki centralne świata. Zasadniczymi obszarami wątpliwości są: cel inflacyjny jako podstawa polityki pieniężnej, skuteczność instrumentów banku centralnego, skutki uboczne ekspansywnej polityki pieniężnej. Oryginalność: Tekst stanowi nowatorskie podejście do analizy polityki makroekonomicznej, gdyż wskazuje na zasadnicze luki w wiedzy ekonomicznej, na bazie której prowadzona jest bieżąca polityka makroekonomiczna Słowa kluczowe: polityka pieniężna, bank centralny, kryzys finansowy
\end{abstract}

\section{Crisis and Monetary Policy - Major Dilemmas}

Primary submission: 11.12.12 | Final acceptance: 20.03.13

\begin{abstract}
Purpose: The goal of the text is to show a number of challenges which major central banks must face today. Impressive engagement of the central banks in counter-crisis policy leads to many controversial decisions and its results are not clear both for economic theory and for real economy. For now, one cannot show a full overview of the policy of central banks - on the one hand, thanks to the expansionary monetary policy, recession was quite shallow and the risk in financial markets has declined, but on the other hand, few side effects of this policy can be mentioned, which can jeopardize economic stability in the future.

Methodology: The paper has a theoretical character. The findings are based on a literature review and an analysis of the major macroeconomic data.

Findings: The text indicates the most important areas which have to be investigated by central banks. There are serious doubts about issues like: inflation targeting as a fundamental part of monetary policy, the efficiency of monetary policy instruments and the side effects of loose monetary policy.

Originality: The text presents quite a new approach in analyzing macroeconomic policy by indicating important gaps in contemporary economic knowledge according to which economic policy is conducted.
\end{abstract}

Keywords: monetary policy, central bank, financial crisis

JEL: E50, E51, E58

\footnotetext{
1 Akademia Leona Koźmińskiego

Adres do korespondencji: Akademia Leona Koźmińskiego, Centrum Badawcze TIGER, ul. Jagiellońska 59, 03-301 Warszawa, e-mail: tomkiewj@kozminski.edu.pl.
} 


\section{Wprowadzenie}

Mimo że od wybuchu kryzysu finansowego minęło już kilka lat, a literatura dotycząca tego problemu jest już bardzo znacząca, to z pewnością nie można mówić o konsensusie wśród ekonomistów co do optymalnej polityki gospodarczej, którą rządy i banki centralne powinny wdrożyć, aby zminimalizować negatywne skutki załamania finansowego i przeciwdziałać podobnym zaburzeniom w przyszłości. Oczywiście, wobec ogromnej liczby osób zajmujących się analizą bieżącego kryzysu trudno oczekiwać jednego stanowiska, ale obecnie nawet nie można mówić o względnie spójnej, jednoznacznej opinii głównych ośrodków analitycznych, za jakie można uznać międzynarodowe instytucje badawcze, takie jak MFW, Bank Światowy czy OECD. Warto w tym miejscu przypomnieć, że przecież poprzednie zaburzenia w gospodarce światowej Wielki Kryzys z lat 1929-1933, stagflacja z lat 70. - raczej doczekały się powszechnie akceptowanej, przynajmniej przez ekonomię głównego nurtu, interpretacji co do ich przyczyn i pożądanej reakcji ze strony polityki gospodarczej.

Celem niniejszego tekstu jest wskazanie dylematów, które nie zostały rozstrzygnięte ani na gruncie teorii ekonomii, ani w praktyce prowadzonej obecnie polityki pieniężnej, co sprawia, że mamy obecnie problematyczną sytuację, kiedy to bardzo dużemu zaangażowaniu się banków centralnych w gospodarkę nie towarzyszy spójna teoria ekonomiczna, która uzasadniałaby stosowanie tych a nie innych instrumentów polityki gospodarczej. Analizowana będzie tylko polityka monetarna. Oczywiście autor zdaje sprawę, że podobne problemy można wskazać chociażby w obszarze zarządzania finansami publicznymi, regulacji czy polityki strukturalnej, ale te kwestie wykraczają poza pole zainteresowania tego tekstu.

\section{Co dalej z celem inflacyjnym?}

Do czasu wybuchu kryzysu finansowego panował konsensus co do zasadniczego kryterium, na którym powinna opierać się polityka banku centralnego. Mimo że amerykański FED (Bank Anglii, EBC i wiele banków centralnych, w tym NBP, stosują metodę bezpośredniego celu inflacyjnego) nie wskazuje określonego poziomu inflacji jako swego oficjalnego celu, nie ma wątpliwości, że to dynamika cen konsumpcyjnych jest najważniejszym parametrem, branym pod uwagę przez władze monetarne w USA. Tak prowadzona polityka pieniężna ewidentnie się nie sprawdziła, tj. nie była w stanie zagwarantować stabilności makroekonomicznej. Mimo stabilnych poziomów inflacji konsumenckiej, nierównowaga makroekonomiczna narastała, mając swój wyraz w bardzo wysokiej dynamice cen aktywów - instrumentów finansowych i nieruchomości - co w sumie doprowadziło do gwałtownego załamania się rynków finansowych z negatywnymi konsekwencjami dla realnej sfery gospodarki. Czy wobec powyższego ceny aktywów powinny być uwzględniane w funkcji reakcji banku centralnego? Czy władze monetarne powinny reagować na powstawanie tzw. bąbli spekulacyjnych? Czy wreszcie banki centralne mają instrumenty, które pozwalałaby na skuteczne reagowanie na to, co się dzieje na rynkach aktywów? Mimo że można wskazać, iż banki centralne brały pod uwagę ceny aktywów 
w swojej polityce (Krześniak i Kalicki, 2010), to zasadniczo oparcie się na polityce celu inflacyjnego raczej wyklucza reagowanie na kształtowanie się baniek spekulacyjnych, chociażby przez konieczność złamania reguły Tinbergena - przy pomocy jednego instrumentu, czyli krótkiej stopy procentowej, nie można jednocześnie oddziaływać na dynamikę cen konsumpcyjnych i cen aktywów (Siwiński, 2011).

Polityka banku centralnego, która byłaby ukierunkowana na przeciwdziałanie powstawaniu baniek spekulacyjnych, budzi poważne wątpliwości co do jej skuteczności, ponieważ przecież można wskazać wiele obiektywnych, trudnych do rozstrzygnięcia problemów (Mishkin, 2011).

Rozpoznanie, że mamy do czynienia z bańką spekulacyjną, a nie naturalnym wzrostem ceny aktywu wynikającym z poprawy perspektyw co do przyszłych przepływów finansowych, wcale nie jest łatwe. Jeśli bank centralny uznałby, że wartość bieżąca danych aktywów przewyższa ich wartość fundamentalną i podjąłby działanie, np. oznaczające podniesienie stóp procentowych, oznaczałoby to, że bank centralny dysponuje wiedzą, jaka jest niedostępna dla graczy rynkowych, więc zasadniczo byłby to problem asymetrii informacji na rynkach finansowych, a nie poziomu parametrów polityki pieniężnej.

Wzrost cen aktywów wynikający z oczekiwań spekulacyjnych jest zwykle bardzo dynamiczny, więc aby mu przeciwdziałać, tj. „odciągnąć” inwestorów od inwestowania w tego typu aktywa, należałoby bardzo mocno zaostrzyć politykę pieniężną, co nie może pozostać bez wpływu na dynamikę w realnej gospodarce.

Spekulacyjny wzrost cen nigdy nie dotyka całego rynku, a instrumenty banku centralnego (stopy procentowe, poziom rezerw obowiązkowych) nie pozwalają przecież na oddziaływanie na wybrane rynki, tym samym więc polityka pieniężna ukierunkowana na przeciwdziałanie wzrostowi baniek miałaby bardzo poważne, negatywne skutki uboczne.

Podwyżka stóp procentowych, która byłaby reakcją na wzrost cen aktywów, może zostać zinterpretowana przez rynek finansowy jako sygnał do zmiany trendu (pęknięcia bańki), co dla inwestorów oznacza konieczność szybkiego pozbycia się aktywów i może prowadzić do gwałtownego załamania się rynku. W takim przypadku polityka pieniężna, która powinna stabilizować rynek, może doprowadzić do jego nagłej destabilizacji.

Uwzględnianie obok dynamiki cen konsumpcyjnych także przyrostów cen aktywów niewątpliwie zmniejsza transparentność i wiarygodność prowadzonej polityki pieniężnej, która powinna opierać się na czytelnych, jednoznacznych zasadach.

Biorąc pod uwagę powyższe, można uznać, że władze monetarne doszły do wniosku, że koszty przeciwdziałania tworzenia się baniek spekulacyjnych były wyższe niż ewentualne koszty związane z koniecznością reakcji na pęknięcie bańki (leaning against vs cleaning up cost). Przemawiają za tym chociażby doświadczenia amerykańskiej gospodarki z roku 2001, kiedy to pękła 
bańka związana z akcjami firm internetowych. Wówczas FED bardzo szybko zareagował, obniżając stopy procentowe, wobec czego recesja była krótka i stosunkowo płytka.

Z dzisiejszej perspektywy ta sytuacja wygląda zupełnie inaczej. Po pierwsze, koszty „sprzątania” po załamaniu rynków finansowych z roku 2008 okazały się ogromne. Po drugie, to właśnie bardzo luźna polityka monetarna FED-u będąca następstwem kryzysu tzw. dotcomów jest często wskazywana jako jedna z poważniejszych przyczyn uruchomienia mechanizmów, które w sumie doprowadziły do wybuchu kryzysu (Rosati, 2009; Roubini, Mihn, 2011).

Jak widać, poziom inflacji konsumenckiej, jako cel dla prowadzenia polityki pieniężnej, budzi poważne zastrzeżenia, a przecież równie problematyczne jest ustalenie konkretnego poziomu dynamiki cen, który byłby optymalny dla gospodarki. Do wybuchu kryzysu panował w tej sprawie konsensus, według którego pożądanym poziomem inflacji jest $2 \%$ rocznie - taki cel inflacyjny jest określony dla EBC i Banku Anglii, NBP „celuje” w 2,5\%. Ustalenie celu inflacyjnego na niskim poziomie wynika z obawy o efekty redystrybucyjne inflacji (im wyższa inflacja, tym wyższa redystrybucja dochodów, która jest jej wynikiem) oraz o tzw. zakotwiczenie oczekiwań inflacyjnych - im niższa inflacja, tym bardziej staje się ona przewidywalna.

Obecny kryzys finansowy ujawnił niebezpieczeństwa, które wcześniej właściwie miały tylko charakter rozważań teoretycznych, takie jak pułapka płynności, deflacja czy granica, jaką dla polityki pieniężnej stanowi poziom stóp procentowych wynoszący 0. Dzisiaj więc można postawić bardzo ważne pytanie, które jeszcze kilka lat wcześniej brzmiałoby jak herezja: dlaczego inflacja na poziomie np. 4\% miałyby być ,gorsza” niż ta na poziomie 2\% (Blanchard, Dell'Ariccia i Mauro, 2010)? Wskazanie wyższego docelowego poziomu inflacji powinno przecież zwiększyć skłonność do konsumpcji, realne stopy procentowe znacznie by spadły, a w przyszłości stopy banku centralnego musiały by być wyższe, co zwiększyłoby możliwości reakcji polityki pieniężnej w obliczu kolejnego spowolnienia. Oczywiście należy sobie zdawać jednak sprawę, że podwyższona inflacja niesie ze sobą wiele niebezpieczeństw, których nie można lekceważyć. Można tutaj wspomnieć chociażby o takich kwestiach jak:

- wyższa inflacja jest mniej przewidywalna, a co za tym idzie, na wyższym poziomie trudno ją ustabilizować;

- redystrybucja dochodów związana z inflacją zarówno w układzie krajowym (ceny vs płace, długi vs oszczędności), jak i zagranicznym (zmiany poziomów realnych kursów walutowych), która utrudnia optymalną alokację zasobów w gospodarce;

- spadek realnej wartości zgromadzonych oszczędności, chociażby tych w systemach emerytalnych w systemie kapitałowym, co ma negatywny wpływ na poziom życia obecnych i przyszłych emerytów, a co za tym idzie, popyt konsumpcyjny.

Podsumowując: na pewno nie ma prostej odpowiedzi na wskazywane wyżej dylematy. Z jednej strony, ewidentnie widać, że osiągnięcie niskiej, stabilnej inflacji nie jest tożsame ze zrównoważoną makroekonomicznie gospodarką. Z drugiej jednak strony, jeśli rozszerzylibyśmy katalog celów banku centralnego o tzw. czynniki makroostrożnościowe (dynamika kredytu, wysokość 
dźwigni finansowej, dynamika cen aktywów, struktura aktywów w portfelach instytucji finansowych itd.), to musimy poszerzyć instrumentarium o wiele kwestii z zakresu regulacji rynku (Szpunar, 2012), co musi negatywnie wpłynąć na przejrzystość prowadzonej przez bank centralny polityki. Nawiasem mówiąc, wobec dużej skali integracji światowych finansów, skuteczność krajowych regulacji może być niewielka, a widać, że koordynacja nadzoru na poziomie ponadnarodowym ma przed sobą jeszcze długą drogę.

Jeśli chodzi o optymalny poziom inflacji, to raczej nie widać, żeby banki centralne z entuzjazmem podeszły do podwyższenia celu inflacyjnego, ale na pewno na politykę pieniężną patrzy się dziś dużo bardziej elastycznie, tj. większą niż wcześniej wagę przywiązuje się do możliwości oddziaływania na sferę realną gospodarki - lukę popytową i wynikającą z niej wysokość bezrobocia.

\section{| Więcej instrumentów do dyspozycji przy spadającej skuteczności podstawowych narzędzi banku centralnego}

W czasach tzw. wielkiego umiarkowania, tj. okresu stabilnego i względnie wysokiego wzrostu gospodarczego, który charakteryzował gospodarki wysoko rozwinięte (poza Japonią) od lat 80. XX w., panowało przekonanie, że krótka stopa procentowa ${ }^{2}$ jest wystarczającym instrumentem, który ma do dyspozycji bank centralny i za pomocą którego można wpływać na bieżący poziom inflacji i stan koniunktury rozumiany jako wielkość luki popytowej.

Inne instrumenty nie były potrzebne, bo doktryna gospodarki rynkowej zakłada, że o długookresowych stopach procentowych przesądza ryzyko inwestowania w danym kraju, które często utożsamia się ze zdolnością rządu do spłaty swego zadłużenia, więc wskaźnikiem jest tutaj rentowność obligacji skarbowych. Pozycja banku centralnego jako kredytodawcy ostatniej instancji była podporządkowana tylko ochronie depozytów zgromadzonych w bankach komercyjnych i w żadnej mierze nie mogła być rozumiana jako instrument polityki strukturalnej, która sprowadzałaby się do podejmowania arbitralnych decyzji o dostarczeniu płynności temu czy innemu podmiotowi, który stanął w obliczu niewypłacalności.

Wobec wybuchu kryzysu finansowego aktywność banków centralnych bardzo wzrosła, zarówno na polu stosowania tradycyjnych instrumentów, jak i szeregu działań, które wcześniej nie były stosowane w polityce pieniężnej. Nowe instrumenty można pogrupować w kilka wiązek (Reis 2010):

1. Polityka tzw. luzowania ilościowego, tj. zwiększania podaży pieniądza przez bank centralny.

2 Pamiętajmy, że praktycznie wszystkie tradycyjne instrumenty banku centralnego, takie jak stopa referencyjna, depozytowa, kredytu lombardowego, operacje otwartego rynku czy poziom rezerw obowiązkowych sprowadzają się do oddziaływania na rynkową stopę procentową 0 krótkim charakterze. 
Regulacja bieżącej płynności przez operacje otwartego rynku jest normalnym, często stosowanym działaniem BC, natomiast na pewno „normalna” nie jest skala wzrostu podaży pieniądza, jaką obserwujemy od roku 2008 - do chwili obecnej sumy bilansowe Banku Anglii i FED-u zwiększyły się ponadtrzykrotnie, niewiele mniej powiększył się bilans EBC (dane BIS).

2. Wydłużenie horyzontu stóp procentowych, na które oddziałuje bank centralny.

Mimo obniżenia stóp banku centralnego w większości gospodarek wysoko rozwiniętych (USA, Wielka Brytania, strefa euro, Japonia) do najniższych w historii poziomów, aktywność systemu finansowego na polu zwiększania kredytowania dla przedsiębiorstw i gospodarstw domowych utrzymuje się na niskim poziomie, m.in. ze względu na duży poziom ryzyka wynikający ze stanu bilansów przedsiębiorstw i gospodarstw domowych. w większości gospodarek. W związku z tym banki centralne podjęły działania, których celem jest obniżenie długoterminowych stóp procentowych, co powinno skłonić banki do finansowania długookresowych inwestycji. Poniżej kilka przykładów na oddziaływanie banków centralnych na długie stopy procentowe:

- wydłużenie horyzontu instrumentów skupowanych przez BC w ramach operacji otwartego rynku - dzisiaj w bilansach FED-u i EBC dłużne papiery skarbowe o zapadalności więcej niż jednego roku stanowią odpowiednio aż około 50 i 30\%,

- we wrześniu 2011 r. FED przeprowadził operację MEP (Maturity Extension Programme), która polegała na wymianie na rynku „krótkich” bonów skarbowych na obligacje o odległych terminach zapadalności,

- w sierpniu 2011 r. szef FED-u ogłosił, że stopy procentowe pozostaną na poziomie 0 co najmniej do roku 2013,

- w grudniu 2011 i lutym 2012 r. EBC przeprowadził dwie rundy operacji LTRO (Long Term Refinancing Operations), które polegały na udzieleniu bankom komercyjnym długoterminowych, bo aż trzyletnich kredytów na kwotę w sumie biliona euro.

3. Poszerzenie zakresu oddziaływania polityki pieniężnej.

Tradycyjna rola państwa na rynku finansowym to przede wszystkim dwa zadania - zapewnienie bezpieczeństwa dla depozytów zgromadzonych w bankach komercyjnych i prowadzenie polityki pieniężnej, ukierunkowanej głównie na stabilizację poziomu cen. Podmiotami mechanizmu transmisji polityki BC są w obu przypadkach banki komercyjne, pozostałe instytucji finansowe, jak banki inwestycyjne czy zakłady ubezpieczeniowe, raczej pozostają poza jego zainteresowaniem. Ilość wzajemnych powiązań instytucjami finansowymi różnego typu sprawiła, że w obawie przed załamaniem rynku finansowego ${ }^{3} \mathrm{BC}$ musi dziś prowadzić politykę ukierunkowaną na praktycznie wszystkie instytucji finansowe. Znowu można wskazać kilka przykładów takiej aktywności BC:

\footnotetext{
3 Pamiętajmy, że impulsem wybuchu kryzysu był upadek Lehmann Brothers. Bank inwestycyjny, jakim był Lehmann Brothers, nie gromadzi depozytów ludności, więc można stwierdzić, że państwo nie powinno się włączać w pomoc dla tego rodzaju instytucji.
} 
- pozycja BC jako kredytodawcy ostatniej instancji, która było zarezerwowana tylko dla banków komercyjnych, tj. takich, które gromadzą depozyty ludności, została rozszerzona na praktycznie wszystkie instytucji finansowe, włącznie z bankami inwestycyjnymi i zakładami ubezpieczeniowymi,

- w ramach operacji otwartego BC akceptuje obecnie cały wachlarz instrumentów finansowych, które wcześniej, ze względu na zbyt duże ryzyko z nimi związane, nie mogły wchodzić w skład bilansu BC ${ }^{4}$,

- BC udziela kredytu lombardowego pod zastaw instrumentów wcześniej nieakceptowanych. Można tutaj przywołać wspominane wcześniej operacje LTRO, w ramach których zabezpieczeniem mogły być papiery o ratingu niższym niż AAA.

Tak duże poszerzenie instrumentarium banku centralnego w dużej mierze wynika z tego, że podstawowe narzędzia polityki monetarnej, tj. krótka stopa procentowa, poziom rezerwy obowiązkowej i tradycyjne regulowanie płynności w ramach otwartego rynku praktycznie pozostają bezużyteczne wobec okoliczności, jakie ukształtowały się na rynkach finansowych w następstwie kryzysu.

Jeśli chodzi o stopy procentowe banku centralnego, pole manewru dla władz monetarnych zostało praktycznie wyczerpane, bo została osiągnięta granica $0 \%{ }^{5}$ (FED, Bank Anglii), a przecież nominalne stopy procentowe nie mogą mieć ujemnego poziomu ${ }^{6}$. Warto przy tym pamiętać, że mimo głębokiego cięcia stóp procentowych banków centralnych, rynkowe stopy procentowe nie zachowują się zgodnie z oczekiwaniami BC. Owszem, rentowności bezpiecznych aktywów mocno spadły, ale w tym samym czasie mocno zwiększyły się różnice między rentownościami papierów bezpiecznych a tymi bardziej ryzykownymi ${ }^{7}$. Mamy więc do czynienia z sytuacją, w której bank centralny obniża swoje stopy, ale nie znajduje to proporcjonalnego przełożenia dla kosztu kapitału, pozyskiwanego przez podmioty gospodarcze inne niż skarb państwa.

Ustalanie minimalnego poziomu rezerw obowiązkowych, które muszą być utrzymywane przez banki komercyjne, straciło praktycznie znaczenie, bo wobec obaw o zdolność kredytową przedsiębiorstw i gospodarstw domowych akcja kredytowa praktycznie zamarła, a co za tym idzie, banki zgromadziły ogromne rezerwy, które nie są praktycznie wykorzystywane dla finansowania rozwoju gospodarki. Od roku 2010 poziom rezerw banków amerykańskich jest stale prawie dwa razy wyższy niż ich wymagany poziom określony przez BC. Taki stan rzeczy oznacza, że jakakolwiek decyzja BC w stosunku do poziomu rezerwy obowiązkowej nie ma żadnego wpływu na płynność rynku.

4 W aktywach FED-u dziś można znaleźć np. niesławne MBS-y (Mortgage Backed Securities) o wartości nominalnej około biliona dolarów.

5 Gdybyśmy chociażby próbowali zastosować regułę Taylora, oznaczałoby to, że stopy nominalne powinny być niższe o jeszcze kilka punktów, bo przeciez presja inflacyjna praktycznie nie występuje, a luka popytowa pozostaje na wciąż na wysokim poziomie.

6 Teoretycznie można sobie wyobrazić, ze bank centralny ustala stopy nominalne na ujemnym poziomie, ale byłoby to wynaturzenie stosunków finansowych - nikt przecież nie będzie lokował środków w lokaty o ujemnym zwrocie, a ujemne oprocentowanie kredytów polegałoby na osiąganiu zwrotu "z niczego", tylko z samego faktu zaciągnięcia długu.

7 Dobrą miarą tego zjawiska są różnice w rentowności papierów dłużnych o różnych poziomach wiarygodności kredytowej. 
Regulowanie płynności przez bank centralny w ramach operacji otwartego rynku również stało się dużo mniej skuteczne, co ma związek z opisanym wyżej zjawiskiem, tj. utrzymywaniem przez banki wysokich rezerw, a co za tym idzie - niskiej aktywności kredytowej. Należy tutaj przypomnieć, że mechanizm mnożnika kreacji pieniądza polega na prowadzeniu operacji kredytowo-depozytowych, a potencjalna wielkość mnożnika wynika z ustalonego przez bank centralny poziomu rezerw obowiązkowych. Jeśli rezerwy banków są wyższe, niż jest to wymagane, to tym samym zmniejsza się wielkość mnożnika, więc zwiększanie podaży pieniądza przez bank centralny (agregat M0 rośnie) nie przekłada się tak szybko na przyrosty szerszych agregatów, tj. M1, M2 czy M3. Nawiasem mówiąc, jeśli obserwuje się dynamikę przyrostów podaży pieniądza przez analizę szerokich agregatów, to nie można znaleźć potwierdzenia dla twierdzeń, że banki centralne „zalały” rynki płynnością - wielkość agregatu M3 w USA i Wielkiej Brytanii, czyli w krajach, które otwarcie stosują politykę luzowania ilościowego, jest dziś niższa niż 4 lata temu (dane FED i Banku Anglii).

Obserwowanie wyjątkowej aktywności banków centralnych prowadzi do co najmniej dwóch pytań:

1. Czy niestandardowe instrumenty zastosowane przez władze monetarne przyniosły pożądane efekty?

2. Czy wobec spadającej efektywności instrumentów banku centralnego warto było je stosować z taką intensywnością, bo przecież taka polityka pieniężna ma swoje skutki uboczne?

Ad 1. Oczywiście można dyskutować o złamaniu, wcześniej wydawałoby się żelaznych, zasad polityki pieniężnej, takich jak stosowanie mechanizmu kredytodawcy ostatniej instancji dla instytucji innych niż tradycyjne banki depozytowo-kredytowe, ale nie można nie zauważyć, że aktywność banków centralnych przyniosła swój efekt (Hamilton i Wu, 2011) - długoterminowe rynkowe stopy procentowe spadły i powróciło zaufanie na rynku międzybankowym, chociażby przez obniżenie długoterminowych stóp procentowych czy powrót względnego zaufania na rynku międzybankowym.

Ad 2. Tak intensywnie prowadzona polityka stymulacyjna musi mieć swoje negatywne efekty, o których będzie mowa dalej, ale stosunkowo łatwo sobie wyobrazić stan gospodarki, gdyby banki centralne powstrzymały się do takiej skali interwencji (Mishkin, 2009).

Po pierwsze, rynkowe stopy procentowe, czyli związane z kredytowaniem podmiotów innych niż te o najwyższym ratingu, wzrosłyby jeszcze bardziej, co oznaczałoby ograniczenie dostępu do finansowania dla wielu podmiotów gospodarczych.

Po drugie, skupienie przez banki centralne całego szeregu ryzykownych aktywów, chociażby MBS-ów, znacznie zmniejszyło ryzyko w systemie, co sprawiło, że rynek finansowy funkcjonuje w miarę sprawnie, a pamiętajmy, że po upadku Lehmann Brothers rynek międzybankowy praktycznie zamarł, bo poszczególne instytucje nie były pewne wypłacalności innych uczestników rynku. 
I wreszcie po trzecie, ekspansywna polityka pieniężna umożliwiła prowadzenie wyjątkowo luźniej polityki fiskalnej, która zaabsorbowała spadek popytu konsumpcyjnego i inwestycyjnego ze strony podmiotów prywatnych, a tym samym skróciła i spłyciła recesję.

\section{| Jak długo można prowadzić superekspansywną politykę pieniężną? Czy ma ona swoje skutki uboczne?}

Nie ulega wątpliwości, że skala kryzysu finansowego, który obserwujemy od roku 2008, wymagała wyjątkowej reakcji ze strony polityki gospodarczej, w tym niestandardowej reakcji banku centralnego. Nie można jednak także mieć złudzeń, że opisane wyżej działania władz monetarnych mogą trwać w nieskończoność, bo przecież:

- kryzys nie uchylił podstawowego założenia makroekonomicznego, według którego inflacja jest przede wszystkim zjawiskiem monetarnym, więc przyrost podaży pieniądza banku centralnego, prędzej czy później, musi przełożyć się na wzrost inflacji,

- banki centralne nie mogą na dłuższą metę utrzymywać w swoich bilansach całego szeregu instrumentów finansowych, bo przecież rolą BC nie jest inwestowanie w taką czy inną dziedzinę gospodarki,

- możliwości prowadzenia przez banki centralne ekspansywnej polityki pieniężnej, nawet tej przy użyciu niestandardowych narzędzi, powoli się wyczerpuje - na rynku finansowym zaczyna brakować aktywów finansowych, które BC mógłby skupować w ramach zwiększania podaży pieniądza.

Wobec powyższego, zasadnicze jest pytanie, czy i kiedy powinien nastąpić odwrót od antykryzysowej, niestandardowej polityki pieniężnej.

Na to pytanie znowu nie ma jednoznacznej odpowiedzi. Z jednej strony, można wskazać, że ożywienie, jakie obserwujemy w gospodarce światowej, trudno uznać za zadowalające, chociażby z punktu widzenia poziomów bezrobocia, i co ważne, dynamika gospodarcza jest niższa niż przewidywano - w ostatnim wydaniu raportu World Economic Outlook (IMF, 2012) wprost przyznaje się, że wcześniejsze prognozy trzeba dziś weryfikować, niestety in minus.

Podobnie jak w przypadku polityki pieniężnej, również luźna polityka fiskalna ma swoje granice, które są określone przez popyt rynków finansowych na papiery skarbowe. Nawet w tych krajach, gdzie nie ma problemu ze zbytem obligacji, takich jak USA czy większość krajów Europy Zachodniej, rządy muszą podjąć wysiłek dostosowania fiskalnego, bo skala kosztów obsługi długu publicznego i, co za tym idzie, przerzucanie zobowiązań na przyszłe pokolenia zaczynają zagrażać stabilności politycznej, a pamiętajmy, że w dłuższym okresie sytuacja systemów finansów publicznych będzie dodatkowo utrudniona na skutek postępujących zmian demograficznych (IMF, 2010a) 
Nie ma jednak złudzeń, że w obliczu obecnego kształtu gospodarki światowej dostosowanie fiskalne musi być mocno prorecesyjne (IMF, 2010b; IMF, 2012; Perotti, 2011), więc jeśli w tym samym czasie zaostrzona zostanie polityka pieniężna, to większość gospodarek pogrąży się w głębokiej recesji.

Z drugiej jednak strony, poziom stóp procentowych wynoszący 0 i aktywność banku centralnego, który przez dłuższy czas masowo skupuje aktywa na rynku finansowym, trudno uznać za stan normalny, można także wskazać cały szereg negatywnych skutków ubocznych takiej polityki, które mogą znacznie osłabić tempo wzrostu w dłuższym okresie (BIS, 2012).

Stopy procentowe na bardzo niskim poziomie nie odgrywają jednej ze swej podstawowej roli, tj. weryfikacji opłacalności inwestycji. Jeśli koszt kapitału wynosi zero, presja na zwiększanie efektywności gospodarowania maleje.

Polityka skupowania przez bank centralny aktywów finansowych i utrzymywanie niskich stóp procentowych pozwala na utrzymywanie w bilansach banków pozycji o wątpliwej jakości. Dotyczy to również sektora publicznego, którego motywacja do strukturalnych reform jest osłabiana przez dostęp do taniego pieniądza na rynku długu.

Obecność banku centralnego na rynku finansowym mocno zniekształca informacje, jakie docierają do uczestników rynku, którzy obserwują wyceny instrumentów finansowych. Przykładowo, czy dziś ktokolwiek jest w stanie określić, jaka jest realna wartość MBS-ów, które znajdują się w bilansie FED-u?

Koszt kapitału bliski zera jest oczywistą zachętą do podejmowania wysokiego ryzyka, aby osiągnąć pożądaną stopę zwrotu, co sprzyja powstawaniu kolejnych baniek spekulacyjnych czy to na rynku surowców, walut, czy chociażby żywności.

Niski poziom stóp procentowych w gospodarkach wysoko rozwiniętych mocno komplikuje także sytuację w gospodarkach wschodzących. Wobec różnicy w oprocentowaniu naturalny jest tzw. mechanizm carry-trade (pożyczanie w walucie o niskich stopach i inwestowanie w walucie dającej wyższe oprocentowanie), co ma swoje negatywne konsekwencje dla gospodarek rozwijających się:

- napływ kapitału aprecjonuje waluty lub zwiększa inflację w krajach rozwijających się, co zmniejsza ich konkurencyjność,

- aby powstrzymać napływ kapitału, banki centralne w krajach biedniejszych także obniżają stopy procentowe, których poziom staje się nieadekwatny z punktu widzenia tamtejszej gospodarki i prowadzi chociażby do spekulacyjnego wzrostu cen aktywów, głównie nieruchomości. 


\section{Podsumowanie}

Z punktu widzenia teorii ekonomii można stwierdzić, że takie wydarzenia jak globalny kryzys finansowy są świetną okazją do zweryfikowania naszej wiedzy o gospodarce, więc ekonomiści powinni być zadowoleni, że mają tak ciekawe pole badawcze. Nie można jednak nie dostrzec, że ekonomiści raczej nie mogą dziś mieć powodów do dumy.

Po pierwsze, wybuch kryzysu był zaskoczeniem praktycznie dla wszystkich, co wskazuje, że teoria, na której oparta była polityka makroekonomiczna rządów i banków centralnych, okazała się nieprzystająca do rzeczywistości.

Po drugie, antykryzysowe działania władz są podejmowane raczej pod wpływem bieżącej sytuacji i intuicji, a nie na zasadzie postępowania według przemyślanej, wewnętrznie spójnej strategii. Taką problematyczną sytuacją jest m.in. zachowanie banków centralnych w większości krajów wysoko rozwiniętych, których zaangażowanie się w stymulowanie gospodarki budzi wiele zastrzeżeń, przede wszystkim w odniesieniu do kosztów tych działań dla długofalowej stabilności gospodarki.

Podsumowując: mimo upływu już ponad 4 lat od początku kryzysu i powstania całkiem sporego dorobku w zakresie jego analizy, dzisiaj zdecydowanie więcej jest pytań niż odpowiedzi, dokąd zmierza gospodarka światowa.

\section{Bibliografia}

BIS (2012). Annual Report 2011/2012. Basel: Bank of International Settlements.

Blanchard, O., Dell'Ariccia, G. i Mauro, P. (2010). Rethinking Macroeconomic Policy, Staff Position Note No. 2010/03, International Monetary Fund.

Hamilton, J.D. i Wu, J.C. (2011). The Effectiveness of Alternative Monetary Policy Tools in a Zero Lower Bound Environment, NBER Working Paper No. 16956.

IMF (a) (2010). From Stimulus to Consolidation: Revenue and Expenditure Policies in Advanced and Emerging Economies, Fiscal Affairs Department. Washington.

IMF (b) (2010). World Economic Outlook. Washington. IMF (2012). World Economic Outlook. Washington.

Kalicki, K. i Krześniak, A. (2010). Polityka pieniężna w strefie euro i USA a ceny aktywów w świetle doświadczeń z kryzysu. W: G.W. Kołodko (red.), Globalizacja, kryzys i co dalej? Warszawa: Poltext.

Mishkin, F.S. (2009). Is Monetary Policy Effective During Financial Crises? NBER Working Paper No. 14678, 2009.

Mishkin, F.S. (2011). Monetary Policy Strategy: Lessons from the Crisis, NBER Working Paper No. 16755.

Perotti, R. (2011). The „Austerity Myth”: Pain Without Gain, BIS Working Paper 362, Basel.

Reis, R. (2010). Interpreting the Unconventional U.S. Monetary Policy of 2007-09, NBER Working Paper No. 15662.

Rosati, D. (2009). Przyczyny i mechanizm kryzysu finansowego w USA. Ekonomista, 3.

Roubini, N. i Mihm, S. (2011). Ekonomia kryzysu. Warszawa: Wolters Kluwer Polska.

Szpunar, P.J. (2012). Rola polityki makroostrożnościowej w zapobieganiu kryzysom finansowym. Materiały i Studia, 278. Narodowy Bank Polski. 